[Original]

\title{
Preparation of 1L-myo-Inositol 1-Phosphate as a Substrate of Phosphatidylinositol Phosphate Synthase
}

\author{
Hiroyuki MoriI $^{1 *}$, Takehiro Nishimura ${ }^{2}$, Masahiro TAKeO ${ }^{2}$, Chika KATAYAma ${ }^{1}$ and Kana NAKaI ${ }^{1}$ \\ ${ }^{1}$ Department of Human, Information and Life Sciences, School of Health Sciences, University of Occupational and \\ Environmental Health, Japan. Yahatanishi-ku, Kitakyushu 807-8555, Japan \\ ${ }^{2}$ Department of Chemistry, School of Medicine, University of Occupational and Environmental Health, Japan. \\ Yahatanishi-ku, Kitakyushu 807-8555, Japan
}

\begin{abstract}
Novel drugs possessing a mechanism of action specific to pathogenic mycobacteria, including Mycobacterium tuberculosis, are needed. In 2010, we discovered that the biosynthetic pathway of phosphatidylinositol, which is a membrane phospholipid, differs between humans and mycobacteria. The key enzyme responsible for this difference is phosphatidylinositol phosphate (PIP) synthase, which is present only in a few bacteria belonging to the phylum Actinobacteria. Discovering compounds that inhibit the activity of this enzyme will lead to the development of new drugs specific to pathogenic mycobacteria. Measuring PIP synthase activity requires the isotope-labeled substrate 1L-myo-inositol 1-phosphate (1L-Ino-1P). Because this substrate is not commercially available, we synthesized it from $\left[{ }^{14} \mathrm{C}\right]$ glucose 6-phosphate $\left(\left[{ }^{14} \mathrm{C}\right] \mathrm{Glc}-6 \mathrm{P}\right)$, using a crude enzyme solution isolated from the methanoarchaeon 1L-Ino-1P synthase. The activity of 1L-Ino-1P synthase in the crude enzyme mixture was low, and quantitative analysis of the synthesized 1L-Ino-1P was inaccurate due to impurities present in the crude enzyme mixture. In the present study, we describe a method for synthesizing 1L-Ino-1P using a solution containing recombinant 1L-Ino-1P synthase derived from the hyperthermophilic archaeon Aeropyrum pernix. In addition, we elucidate the conditions leading to the almost complete conversion of Glc-6P into 1L-Ino-1P using this enzyme. Quantitation of the synthesized 1L -Ino-1P was performed by colorimetry and gas liquid chromatography. Further, we confirmed that isotope-labeled 1L-Ino-1P, which is difficult to quantitate by gas liquid chromatography, can be accurately quantified by colorimetry. We also confirmed that 1D-inositol 1-phosphate cannot be a substrate for PIP synthase.
\end{abstract}

Keywords : inositol, phospholipid, phosphatidylinositol phosphate.

(Received April 20, 2018, accepted August 27, 2018)

\section{Introduction}

Mycobacterium tuberculosis is a pathogen that causes many deaths worldwide [1]. Tuberculosis is treated with several antituberculosis drugs, such as isoniazid, rifampicin, and streptomycin, but increased infection by mycobacteria resistant to multiple antitu- berculosis drugs has become a problem. Group outbreaks of tuberculosis infection still occur in Japan, although the tuberculosis morbidity rates continue to decrease. The prevalence of infectious diseases caused by nontuberculous mycobacteria is rapidly increasing, but effective treatment for these diseases has not yet been established [2]. Novel drugs with a mechanism

*Corresponding Author: Hiroyuki MoriI, Department of Human, Information and Life Sciences, School of Health Sciences, University of Occupational and Environmental Health, Japan. 1-1 Iseigaoka, Yahatanishi-ku, Kitakyushu 807-8555, Japan, Tel: +81-93-603-1611, Fax: +81-93-6917142,E-mail: h-morii@health.uoeh-u.ac.jp 
of action specific to pathogenic mycobacteria, including M. tuberculosis, are needed.

In 2010, we discovered that the synthetic pathway of phosphatidylinositol (PI) in membrane phospholipids differs between mycobacteria and humans [3]. In mycobacteria, 1L-myo-inositol 1-phosphate (1L-Ino1P) synthesized from glucose 6-phosphate (Glc-6P) reacts with cytidine diphosphate diacylglycerol (CDPDAG) to produce an intermediate compound, phosphatidylinositol phosphate (PIP), in which an extra phosphate is attached to PI (Fig. 1). The phosphate is then removed to produce PI. In humans, free inositol, in which the phosphate has been removed from 1L-Ino-
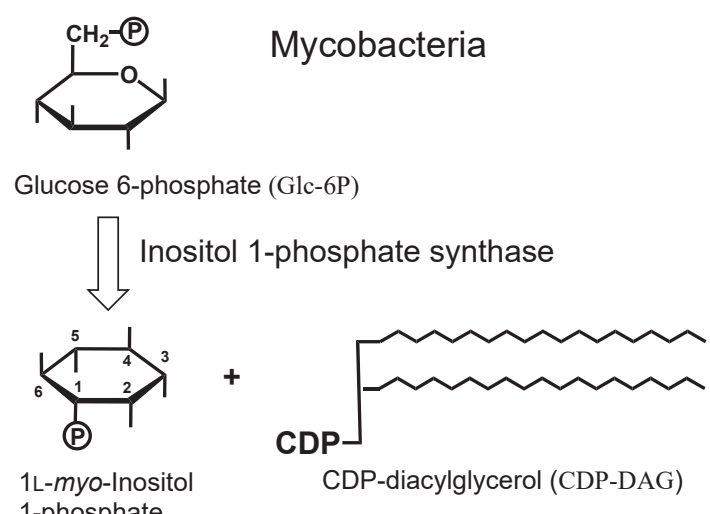

1L-myo-Inositol

(1L-Ino-1P)
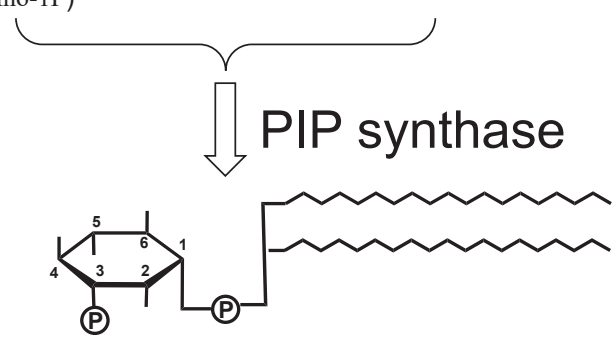

Phosphatidylinositol phosphate (PIP)

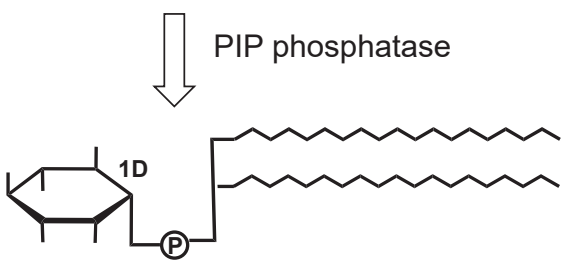

Phosphatidylinositol (PI)
$1 \mathrm{P}$, reacts with CDP-DAG, so that PIP is not produced during the PI biosynthetic process. In mycobacteria, the membrane phospholipid component PI, which is synthesized via PIP, is a starting compound for the biosynthesis of lipoarabinomannan, a structural component of the cell wall. In all mycobacteria, including $M$. tuberculosis, lipoarabinomannan plays an important role in enabling the bacteria to elude the host immune system [4-6]. Therefore, discovering compounds that inhibit PIP biosynthesis in M. tuberculosis will lead to the development of new drugs that specifically inhibit the growth of pathogenic mycobacteria without affecting humans. Bacteria that belongs to genera other than

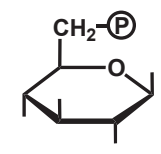

Humans

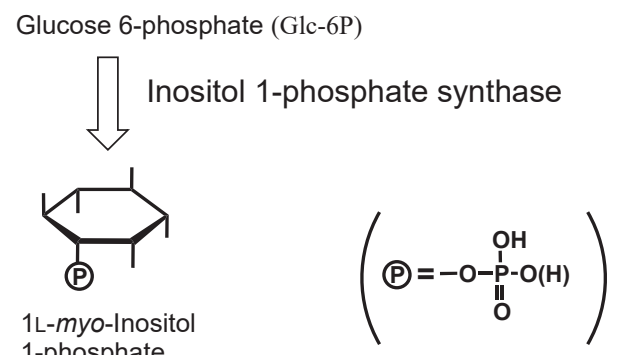

(1L-Ino-1P)
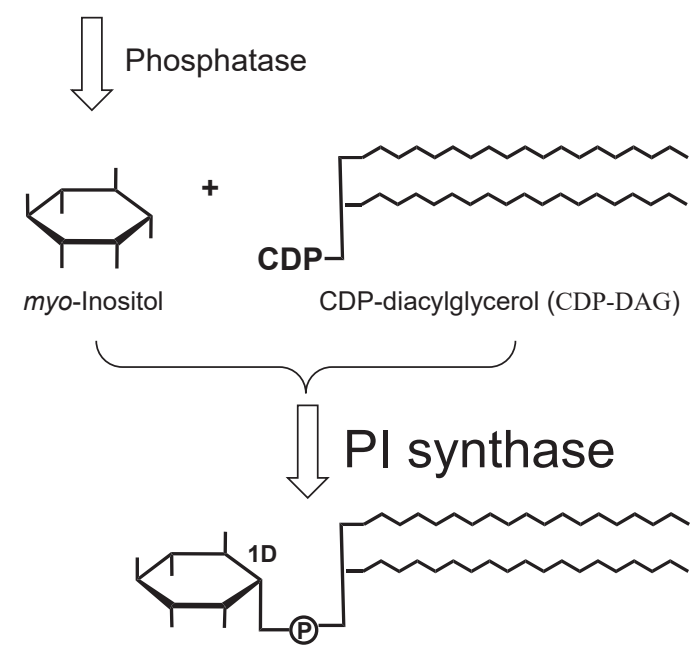

Phosphatidylinositol (PI)

Fig. 1. Biosynthetic pathway of phosphatidylinositol in mycobacteria and humans. Reproduced modification from ref. (Morii H et al (2013): Studies of inositol 1-phosphate analogues as inhibitors of the phosphatidylinositol phosphate synthase in mycobacteria. J Biochem 153: 257-266, Fig. 1. Biosynthetic pathway of phosphatidylinositol in mycobacteria and humans [9]), with permission of the Japanese Biochemistry Society. 
Actinomyces do not possess PI, so it should be possible to develop drugs that do not affect endogenous bacteria important to humans, but are able to specifically inhibit M. tuberculosis and its related pathogenic bacteria by targeting mycobacteria-specific PIP synthase.

Phosphatidylinositol phosphate (PIP) synthase activity was measured using $\left[{ }^{14} \mathrm{C}\right] 1 \mathrm{~L}-$ Ino- $1 \mathrm{P}$ as the substrate. Isotope-labeled $1 \mathrm{~L}$-Ino-1P is not commercially available, and must therefore be prepared from $\left[{ }^{14} \mathrm{C}\right] \mathrm{Glc}-6 \mathrm{P}$. Until now, $\left[{ }^{14} \mathrm{C}\right] 1 \mathrm{~L}-$-Ino-1P has been prepared from $\left[{ }^{14} \mathrm{C}\right]$ Glc-6P using the supernatant of homogenized methanoarchaeon, which is a crude mixture of enzymes that includes 1L-Ino-1P synthase [3, 7-9]. Quantification of 1L-Ino-1P prepared from the crude enzyme mixture is performed by colorimetric measurement of inorganic phosphate released after $\mathrm{NaIO}_{4}$ oxidation [10]. Inorganic phosphate is not released from Glc-6P by $\mathrm{NaIO}_{4}$ oxidation. In a reaction mixture containing the crude enzyme mixture and 1L-Ino-1P formed from Glc-6P, however, $87 \%$ of the inorganic phosphate released after $\mathrm{NaIO}_{4}$ oxidation is due to the release of inorganic phosphate from the crude enzyme mixture alone. A high inorganic phosphate background would interfere with the measurement of 1L-Ino-1P. Although an accurate concentration of 1L-Ino-1P is not required for detecting only the presence of PIP synthase activity, it is definitely necessary for examining the nature of PIP synthase in detail and for verifying its inhibitor. Therefore, we studied the optimum conditions for preparing 1L-Ino-1P using a solution containing recombinant 1L-Ino-1P synthase derived from Aeropyrum pernix and quantitated the production of 1L-Ino-1P by colorimetry and gas liquid chromatography (GLC). We also examined whether commercially available [ $\left.{ }^{3} \mathrm{H}\right]$ 1D-inositol 1-phosphate can be a substrate for PIP synthase.

\section{Materials and Methods}

\section{Materials}

A solution of thermostable, recombinant inositol 1-phosphate synthase was obtained from Wako Pure Chemical Industries, Ltd. (Tokyo, Japan). D-Glucose 6-phosphate (Glc-6P) and 1D-myo-inositol 1-monophosphate (1D-Ino-1P) were purchased from SigmaAldrich (Tokyo, Japan). DL-myo-inositol 1-phosphate was purchased from Biochem AG (Bubedorf, Switzer- land). CDP-dioleoylglycerol \{CDP-DAG (dioleoyl)\} was chemically synthesized from 1,2-dioleoyl-sn-glycero3-phosphate (Avanti Polar Lipids Inc., Alabaster, AL, USA), as described previously [11]. Glucitol 6-phosphate was prepared by $\mathrm{NaBH}_{4}$ reduction of D-Glc-6P [12]. $\left[{ }^{14} \mathrm{C}(\mathrm{U})\right]$ Glucose 6-phosphate $(3.7 \mathrm{MBq} / \mathrm{ml})$ was obtained from Moravek Biochemicals, Inc. (Brea, CA, USA). [2- ${ }^{3} \mathrm{H}$ ] 1D-myo-Inositol 1-phosphate (1.85 MBq/ $\mathrm{m} l$ ) was obtained from American Radiolabeled Chemicals, Inc. (St. Louis, MO, USA).

Preparation of 1L-myo-inositol 1-phosphate (1L-Ino-1P) using a crude enzyme

1L-myo-Inositol 1-phosphate (1L-Ino-1P) was prepared from Glc-6P using a crude enzyme as follows. Cells of Methanothermobacter thermautotrophicus (DSM 1053) were grown and harvested at log phase, as described previously [11]. The M. thermautotrophicus cells were washed twice with $5 \mathrm{mM}$ dithiothreitol (DTT). The pelleted cell paste was stored at $-20^{\circ} \mathrm{C}$ until use. The frozen $M$. thermautotrophicus cells were thawed in $10 \mathrm{ml}$ of $5 \mathrm{mM}$ DTT containing $5 \mathrm{mg}$ deoxyribonuclease I (DNase I) (Sigma-Aldrich) and passed through a French pressure cell operated at $1,400 \mathrm{~kg} / \mathrm{cm}^{2}$. This process was repeated three times. Cell debris and unbroken cells were removed by centrifugation $(10,000 \times g)$ for $10 \mathrm{~min}$. The resultant homogenate was centrifuged at $100,000 \times g$ for $2 \mathrm{~h}$ to separate the supernatant and membrane fractions. The supernatant fraction was used as a crude enzyme containing 1L-Ino-1P synthase. The complete reaction mixture (final volume, $5.0 \mathrm{ml}$ ) contained the supernatant fraction of $M$. thermautotrophicus homogenates (59.5 mg protein), $50 \mathrm{mM}$ bicine buffer ( $\mathrm{pH} 8.5$ ), 0.5 mM Glc-6P, 5 mM nicotinamide adenine dinucleotide (NAD), $1 \mathrm{mM}$ DTT, and $1 \mathrm{mM}$ ammonium acetate. The reaction mixture was incubated at $60^{\circ} \mathrm{C}$ for $2 \mathrm{~h}$. After incubation, it was filtered with an Ultrafilter (USY-1 M=10,000, Advantec) to remove macromolecular compounds. The filtrate contained 1L-Ino-1P, unreacted Glc-6P, and other low molecular-weight compounds in the reaction mixture.

Preparation of 1L-myo-inositol 1-phosphate (1L-Ino-1P) using a recombinant enzyme

1L-myo-inositol 1-phosphate (1L-Ino-1P) was pre- 
pared from Glc-6P using a solution containing recombinant 1L-Ino-1P synthase produced by expressing the relevant gene from A. pernix. The complete reaction mixture (final volume, $0.25 \mathrm{ml}$ ) contained the recombinant enzyme (0.032 units), $40 \mathrm{mM} \mathrm{NaHCO} 3(\mathrm{pH}$ 9.0), 0.5 2.0 mM D-Glc-6P, $1 \mathrm{mM}$ NAD, and $15 \mathrm{mM}$ $\mathrm{NH}_{4} \mathrm{Cl}$. The reaction mixture was incubated at $85^{\circ} \mathrm{C}$ for 5 90 $\mathrm{min}$.

\section{Measurement of 1L-myo-inositol 1-phosphate (1L-Ino-1P) by colorimetry}

Synthesized 1L-Ino-1P was measured essentially based on the measurement of inorganic phosphate (Pi) released by periodate oxidation of myo-inositol 1-phosphate, as described by Barnett et al [10]. The reaction mixture $(0.5 \mathrm{ml})$ of 1L-Ino-1P prepared from Glc-6P using the enzyme was stopped by the addition of 0.2 $\mathrm{m} l$ of $20 \%(\mathrm{w} / \mathrm{v})$ trichloroacetic acid. The precipitated protein was removed by centrifugation and the supernatant was incubated at $37^{\circ} \mathrm{C}$ for $1 \mathrm{~h}$ with $0.2 \mathrm{M} \mathrm{NaIO}_{4}$, after which $1 \mathrm{M} \mathrm{Na}_{2} \mathrm{SO}_{3}$ was added to destroy excess $\mathrm{NaIO}_{4}$ and liberated $\mathrm{Pi}$ was measured using the method of Bartlett [13]. The net Pi value was obtained by subtracting the blank value of the reaction mixture that received $\mathrm{Na}_{2} \mathrm{SO}_{3}$ before the addition of $\mathrm{NaIO}_{4}$.

\section{Measurement of 1L-myo-inositol 1-phosphate (1L-Ino-1P) by gas liquid chromatography (GLC)}

After incubation of 1L-Ino-1P prepared from Glc$6 \mathrm{P}$ using the enzyme, the reaction mixture was filtered with an Ultrafilter (USY-1 M $=10,000$, Advantec) to remove macromolecular compounds without the addition of trichloroacetic acid. Glucitol 6-phosphate was added to the supernatant as an internal GLC standard, followed by evaporation at $40^{\circ} \mathrm{C}$ in a water bath under nitrogen gas and dryness in a high vacuum. This dried residue was trimethylsilylated in trimethylchloros ilane:hexamethyldisilazane: anhydrous pyridine $=2: 2: 5$ (v/v) at $80^{\circ} \mathrm{C}$ for $10 \mathrm{~min}$. DL-myo-inositol 1-phosphate was similarly trimethylsilylated and used as the GLC standard. Gas liquid chromatography (GLC) was performed using a Shimadzu GC-14B gas-liquid chromatograph equipped with flame ionization detectors. Trimethylsilylated inositol 1-phosphate was chromatographed on a 2-m glass column packed with $3 \% \mathrm{OV}-17$ on Uniport HP (80-100 mesh) at $215^{\circ} \mathrm{C}$.
Measurement of phosphatidylinositol phosphate (PIP) synthase activity

The complete assay mixture (final volume, $0.2 \mathrm{ml}$ ) contained $0.1 \mathrm{mM}\left[{ }^{14} \mathrm{C}\right] 1 \mathrm{~L}-\mathrm{Ino}-1 \mathrm{P}(20 \mathrm{nmol}, 11.8 \mathrm{kBq})$ or $0.1 \mathrm{mM}\left[{ }^{3} \mathrm{H}\right]$ 1D-Ino $1 \mathrm{P}(20 \mathrm{nmol}, 18.5 \mathrm{kBq}), 40 \mathrm{nmol}$ CDP-DAG, $50 \mathrm{mM}$ bicine buffer (pH 8.0), $10 \mathrm{mM}$ $\mathrm{MgCl}_{2}$, and $20 \mu \mathrm{g}$ protein of $E$. coli-pET21a-BCG-PIPS membrane fraction [3]. The sequence of the cloned PIP synthase gene of Mycobacterium bovis BCG was the same as that of M. tuberculosis (CAE55505.1). The reaction mixture was incubated at $37^{\circ} \mathrm{C}$ for $30 \mathrm{~min}$. After incubation, the mixture of the reactants and product was partitioned into aqueous and organic components with $2.5 \mathrm{ml} \mathrm{CHCl}_{3}, 2.5 \mathrm{ml}$ of $0.1 \mathrm{M} \mathrm{HCl}$ in methanol, and $2.05 \mathrm{ml}$ of $1 \mathrm{M} \mathrm{MgCl}_{2}$. The radioactivity in the chloroform-soluble organic materials was counted using a liquid scintillation spectrometer (Aloka LSC-8000, Japan) with Aquasol-2 (Packard, Meriden, CT) as the scintillation cocktail.

\section{Results and Discussion}

1L-myo-inositol 1-phosphate (1L-Ino-1P), a PIP synthase substrate, was prepared from Glc-6P using a crude enzyme solution (1L-Ino-1P synthase) contained in the supernatant of homogenized M. thermautotrophicus. Many components of this crude enzyme solution release inorganic phosphate after $\mathrm{NaIO}_{4}$ oxidation, which reduces the reliability of quantitative measurement of $1 \mathrm{~L}-$ Ino-1P. Therefore, we performed partial purification of the crude enzyme solution using ammonium sulfate fractionation, gel filtration, and ultrafiltration. We observed almost no 1L-Ino-1P synthase activity, however, in the partially purified enzyme solution (data not shown).

1L-myo-inositol 1-phosphate (1L-Ino-1P) was prepared from Glc-6P using a solution containing recombinant 1L-Ino-1P synthase produced by expressing the relevant gene from A. pernix. Inorganic phosphate was not released in this enzyme solution without substrate after $\mathrm{NaIO}_{4}$ oxidation (data not shown). The activities of the crude and recombinant enzymes are shown in Table 1. Figure 2 shows the time-course of the ratios of the 1L-Ino-1P formed from Glc-6P. The 1L-Ino-1P was measured by colorimetry. Free inorganic phosphate Pi was released after $\mathrm{NaIO}_{4}$ oxidation of the 1L-Ino1P produced from $0.5,1.0$, and $2.0 \mathrm{mM}$ Glc-6P using 
Table 1. Determination of 1L-inositol 1-phosphate (1L-Ino1P) after an inositol 1-phosphate synthase (IPS) reaction using crude and recombinant enzyme

\begin{tabular}{|c|c|c|c|c|}
\hline \multirow[t]{2}{*}{ Glc-6P } & \multirow{2}{*}{$\begin{array}{l}\text { Enzyme } \\
\text { (origin of IPS) }\end{array}$} & \multirow{2}{*}{$\begin{array}{l}\text { Assay } \\
\text { Condition }\end{array}$} & \multicolumn{2}{|c|}{ 1L-Ino-1P $(\mathrm{mM})^{\mathrm{a}}$} \\
\hline & & & $\mathrm{NaIO}_{4}-\mathrm{Pi}^{b}$ & $\mathrm{GLC}^{\mathrm{c}}$ \\
\hline $0.5 \mathrm{mM}$ & $\begin{array}{l}\text { Crude }^{\mathrm{d}} \\
\text { (M. thermautotrophicus) }\end{array}$ & $\begin{array}{l}60^{\circ} \mathrm{C} \\
2 \mathrm{~h}\end{array}$ & $0.266 \pm 0.004$ & - \\
\hline $0.5 \mathrm{mM}$ & $\begin{array}{l}\text { Recombinant }^{\mathrm{e}} \\
\text { (A. pernix) }\end{array}$ & $\begin{array}{l}85^{\circ} \mathrm{C} \\
1 \mathrm{~h}\end{array}$ & $0.492 \pm 0.018$ & 0.508 \\
\hline $2.0 \mathrm{mM}$ & $\begin{array}{l}\text { Recombinant }^{\mathrm{e}} \\
\text { (A. pernix })\end{array}$ & $\begin{array}{l}85^{\circ} \mathrm{C} \\
1 \mathrm{~h}\end{array}$ & $0.784 \pm 0.008$ & 0.776 \\
\hline
\end{tabular}

${ }^{\mathrm{a}}$ : Concentration of $1 \mathrm{~L}-\mathrm{Ino}-1 \mathrm{P}$ in the enzyme reaction mixture, ${ }^{\mathrm{b}}$ : 1L-Ino-1P was measured by colorimetric measurement of the inorganic phosphate released after $\mathrm{NaIO}_{4}$ oxidation, ${ }^{\mathrm{c}}:$ 1L-Ino-1P was measured by GLC using glucitol 6-phosphate as an internal standard, ${ }^{\mathrm{d}}$ : crude enzyme, homogenate of $M$. thermautotrophicus (59.5 mg protein $/ 5.0 \mathrm{ml}$ well), ${ }^{\mathrm{e}}$ : recombinant enzyme derived from A. pernix (0.032 units $/ 0.25 \mathrm{~m} l$ well). Glc-6P: D-glucose 6-phosphate, GLC: gas liquid chromatography

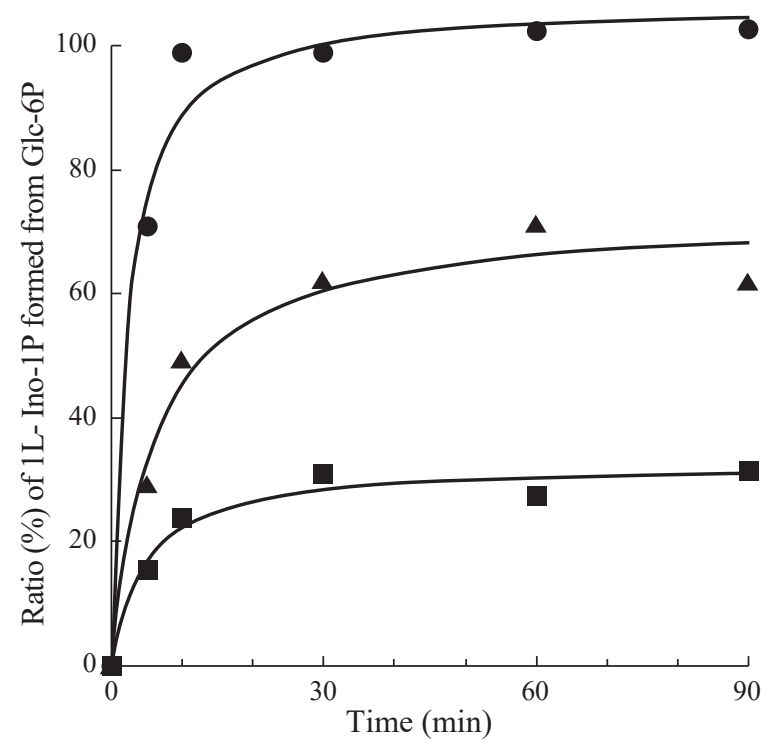

Fig. 2. Time-course of the ratios of 1L-Ino-1P formed from glucose 6-phosphate (Glc-6P). 1L-Ino-1P were prepared from : $0.5 \mathrm{mM}$ Glc-6P, $\mathbf{\Delta}$ : $1.0 \mathrm{mM}$ Glc-6P, $\boldsymbol{\square}: 2.0 \mathrm{mM}$ Glc-6P using the recombinant enzyme at $80^{\circ} \mathrm{C}$, and then the reaction mixture was incubated with $0.1 \mathrm{mM} \mathrm{NaIO}_{4}$. The released $\mathrm{Pi}$, which is correlated with the amount of 1L-Ino-1P, was measured by colorimetry. 1L-Ino-1P: 1L-inositol 1-phosphate.

the recombinant enzyme. The released Pi was measured by colorimetry. Almost all the Glc-6P reacted within $30 \mathrm{~min}$ when the concentration of Glc-6P was $0.5 \mathrm{mM}$, and the amount of Pi did not change thereafter. When the same reaction was performed with Glc-6P at concentrations of 1.0 and $2.0 \mathrm{mM}$, the reaction rates slowed within approximately 30 min under both concentrations. Moreover, the reactions did not progress further, leaving a large amount of unreacted Glc-6P.

It is difficult to analyze isotope-labeled 1L-Ino1P by GLC; therefore, a simple quantitative method (colorimetry) must be established to analyze it. The quantitative analysis results for 1L-Ino-1P obtained by colorimetry and GLC are shown in Table 1. Analysis with GLC revealed that the products obtained from the crude enzyme reaction solution had many compound peaks in addition to 1L-Ino-1P and Glc-6P. Because a peak appearing in the same position as the internal standard glucitol 1-phosphate was detected, it was not possible to quantitate 1L-Ino-1P by GLC. When the recombinant enzyme was used, the concentration of 1L-Ino-1P measured by GLC was the same as that measured by colorimetry (Table 1). Therefore, a simple quantitative method can be used to accurately measure the concentration of (isotope-labeled) 1L-Ino-1P.

On the basis of these results, we established the following method for preparing a substrate necessary for measuring PIP synthase activity: addition of the recombinant enzyme ( 0.032 units $/ 0.25 \mathrm{~m} l$ well $)$ derived from A. pernix to Glc-6P (to a final concentration of $0.5 \mathrm{mM}$ ), followed by heat treatment for $1 \mathrm{~h}$ at $85^{\circ} \mathrm{C}$. The 1L-Ino-1P prepared using the method described above contained very little Glc-6P. In a previous method for measuring of PIP synthase activity, $\left[{ }^{14} \mathrm{C}\right]$ 1L-Ino-1P prepared using a crude enzyme solution was used despite a large amount of unreacted $\left[{ }^{14} \mathrm{C}\right] \mathrm{Glc}-6 \mathrm{P}$ in the solution. The concentration of $1 \mathrm{~L}-$ Ino-1P prepared according to the newly established method was $0.5 \mathrm{mM}$. When PIP synthase activity is measured, 0.1 $\mathrm{mM}$ 1L-Ino-1P is usually used; therefore, the prepared 1L-Ino-1P should be diluted 5-fold. The concentration of 1L-Ino-1P can be accurately determined by colorimetric measurement of the inorganic phosphate released after $\mathrm{NaIO}_{4}$ oxidation, and thereafter inhibitors of PIP synthase can readily be discovered.

The three-dimensional structure of the inositolcontaining polar head region of PI, which is 1D-myoinositol 1-phosphate, is identical in mycobacteria and humans (Fig. 1). A novel pathway for the synthesis of inositol phospholipids using CDP-inositol as the donor of the polar head group in the thermophilic bacterium Rhodothermus marinus was recently reported [14]. 


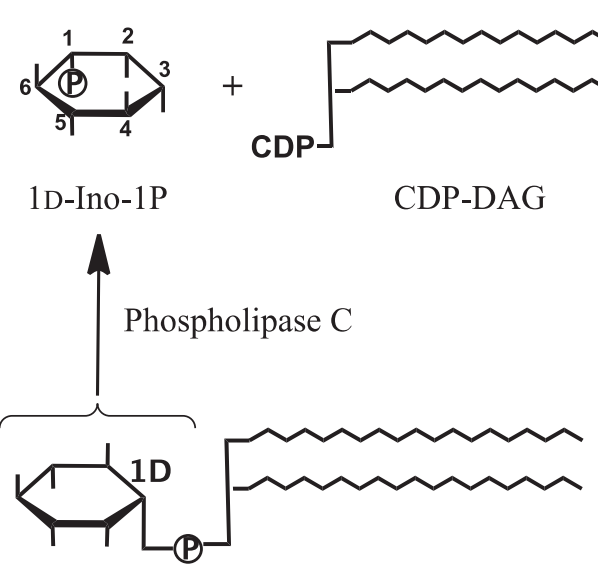

PI (Mycobacteria, Humans)

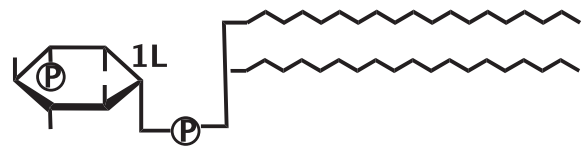

PIP

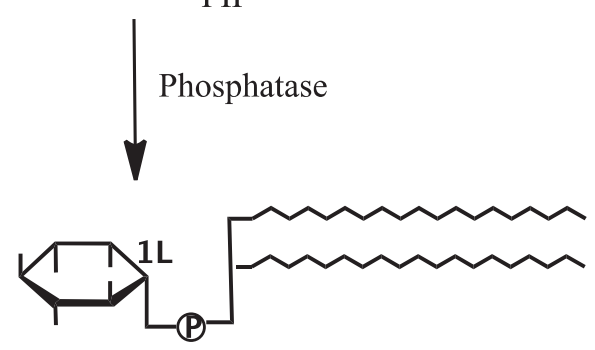

PI (R. marinus)

Fig. 3. Structural relations among 1D-myo-inositol 1-phosphate (1D-Ino-1P), phosphatidylinositol phosphate (PIP) and phosphatidylinositol (PI) in mycobacteria, humans and $\boldsymbol{R}$. marinus. A PI with the same structure as that of $R$. marinus could be created using a phosphatase on the product formed by PIP, provided that PIP synthase can utilize 1D-Ino-1P as a substrate. CDP: cytidine diphosphate, CDP-DAG: CDP-diacylglycerol.

The configuration of CDP-inositol is CDP-1L-myoinositol [15]. Therefore, the configuration of the inositol-containing polar head region of PI in $R$. marinus is $1 \mathrm{~L}$-myo-inositol 1-phosphate, not 1D-myo-inositol 1-phosphate (Fig. 3). A PI with the same structure as that of $R$. marinus could be created using a phosphatase on the product formed by PIP, provided that PIP synthase can utilize 1D-Ino-1P as a substrate (Fig. 3).

The $\left[{ }^{14} \mathrm{C}\right] 1 \mathrm{~L}-$ Ino-1P prepared using the method developed in this study and commercially available $\left[{ }^{3} \mathrm{H}\right]$ 1D-Ino-1P were used as substrates to examine the PIP synthase activity of each. The PIP synthase activity, as measured colorimetrically, was high $(76.2 \pm 1.2 \mathrm{nmol} / \mathrm{h} /$ $\mathrm{mg}$ ) when using $\left[{ }^{14} \mathrm{C}\right] 1 \mathrm{~L}-$ Ino-1P as the substrate, and almost nonexistent $(<0.2 \mathrm{nmol} / \mathrm{h} / \mathrm{mg})$ when using $\left[{ }^{3} \mathrm{H}\right] 1 \mathrm{D}-$ Ino-1P as the substrate (Table 2). 1D-Ino-1P is

Table 2. Substrate specificity of phosphatidylinositol phosphate (PIP) synthase in mycobacteria

\begin{tabular}{lc}
\hline Substrate & $\begin{array}{r}\text { PIP synthase specific activity } \\
(\mathrm{nmol} / \mathrm{h} / \mathrm{mg})\end{array}$ \\
\hline 1L-Ino-1P & $76.2 \pm 1.2$ \\
1D-Ino-1P & $<0.2$ \\
\hline
\end{tabular}

The assay conditions are described in Materials and Methods. Source of enzyme was E. coli-pET21a-BCG-PIPS membrane fraction. 1L-Ino-1P: 1L-myo-inositol 1-phosphate, 1D-Ino-1P: 1Dmyo-inositol 1-phosphate produced when PI is decomposed by phospholipase C in mycobacteria. 1D-Ino-1P, however, is not a substrate for PIP synthase (Fig. 3).

\section{Conflict of Interest}

The authors declare no conflict of interest.

\section{References}

1. World Health Organization (WHO) (2017): Executive Summary. Global tuberculosis report 2017. WHO, Geneva http://www.who.int/tb/publications/global_report/ en/ [Accessed August 27, 2018]

2. Namkoong H, Kurashima A, Morimoto K, Hoshino Y, Hasegawa N, Ato M \& Mitarai S (2016): Epidemiology of pulmonary nontuberculous mycobacterial disease, Japan. Emerg Infect Dis 22: 1116-1117

3. Morii H, Ogawa M, Fukuda K, Taniguchi H \& Koga Y (2010): A revised biosynthetic pathway for phosphatidylinositol in Mycobacteria. J Biochem 148: 593-602

4. Brennan PJ \& Crick DC (2007): The cell-wall core of Mycobacterium tuberculosis in the context of drug discovery. Curr Top Med Chem 7: 475-488

5. Brennan PJ \& Nikaido H (1995): The envelope of mycobacteria. Annu Rev Biochem 64: 29-63

6. Fratti RA, Chua J, Vergne I \& Deretic V (2003): Myco- 
bacterium tuberculosis glycosylated phosphatidylinositol causes phagosome maturation arrest. Proc Natl Acad Sci USA 100: 5437-5442

7. Morii H, Kiyonari S, Ishino Y \& Koga Y (2009): A novel biosynthetic pathway of archaetidyl-myo-inositol via archaetidyl-myo-inositol phosphate from CDP-archaeol and D-glucose 6-phosphate in methanoarchaeon Methanothermobacter thermautotrophicus cells. J Biol Chem 284: 30766-30774

8. Morii H, Ogawa M, Fukuda K \& Taniguchi H (2014): Ubiquitous distribution of phosphatidylinositol phosphate synthase and archaetidylinositol phosphate synthase in Bacteria and Archaea, which contain inositol phospholipid. Biochem Biophys Res Commun 443: 86-90

9. Morii H, Okauchi T, Nomiya H, Ogawa M, Fukuda K \& Taniguchi H (2013): Studies of inositol 1-phosphate analogues as inhibitors of the phosphatidylinositol phosphate synthase in mycobacteria. J Biochem 153: 257-266

10. Barnett JEG, Brice RE \& Corina DL (1970): A colorimetric determination of inositol monophosphates as an assay for D-glucose 6-phosphate-1L-myoinositol 1-phosphate cyclase. Biochem J 119: 183-186
11. Morii H, Nishihara M \& Koga Y (2000): CTP: 2,3-di-Ogeranylgeranyl-sn-glycero-1-phosphate cytidyltransferase in the methanogenic archaeon Methanothermobacter thermoautotrophicus. J Biol Chem 275: 36568-36574

12. Majumder AL \& Eisenberg F Jr (1974): The formation of cyclic inositol 1,2-monophosphate, inositol 1-phosphate, and glucose 6-phosphate by brain preparations stimulated with deoxycholate and calcium: a gas chromatographic study. Biochem Biophys Res Commun 60: 133-139

13. Bartlett GR (1959): Phosphorus assay in column chromatography. J Biol Chem 234: 466-468

14. Jorge CD, Borges N \& Santos H (2015): A novel pathway for the synthesis of inositol phospholipids uses cytidine diphosphate (CDP)-inositol as donor of the polar head group. Environ Microbiol 17: 2492-2504

15. Rodrigues MV, Borges N, Henriques M, Lamosa $P$, Ventura R, Fernandes C, Empadinhas N, Maycock C, da Costa MS \& Santos H (2007): Bifunctional CTP: inositol-1-phosphate cytidylyltransferase/CDP-inositol: inositol-1-phosphate transferase, the key enzyme for di-myo-inositol phosphate synthesis in several (hyper) thermophiles. J Bacteriol 189: 5405-5412 
ホスファチジルイノシトールリン酸合成酵素の基質1L-イノシトール1リン酸の調製法

森井 宏幸 ${ }^{1}$, 西村 壮広 ${ }^{2}$, 竹尾 政宏 ${ }^{2}$, 片山 知郁 ${ }^{1}$, 中井 佳奈 ${ }^{1}$

1産業医科大学 産業保健学部 看護学科 人間情報科学講座

2 産業医科大学 医学部 生体物質化学講座

要旨：結核菌を含めた病原性抗酸菌に特異的な活性作用機序を持った新薬の開発が求められている。我々は 2010年に膜リン脂質のホスファチジルイノシトールの生合成経路がヒトと抗酸菌とで異なる事を発見した。相違 点の鍵となる酵素がホスファチジルイノシトールリン酸(PIP) 合成酵素である。この酵素は放線菌門の一部の細菌 のみに存在し，ヒトやヒトの常在細菌には存在しない。この酵素活性を阻害する化合物を見つけることができれば 病原性抗酸菌に特異的な新薬の開発に繋がる.PIP合成酵素活性測定には, 基質としてアイソトープでラベルされた 1L-イノシトール 1 リン酸(1L-Ino-1P) が必要である。この基質は市販されていないので, これまでは $\left[{ }^{14} \mathrm{C}\right]$ グルコース 6リン酸 $\left(\left[{ }^{14} \mathrm{C}\right] \mathrm{Glc}-6 \mathrm{P}\right)$ からメタン生成古細菌の粗酵素を1L-Ino-1P合成酵素として使って調製していた。この粗酵素 の活性は低く, 粗酵素中の不純物の影響で生成物の 1L-Ino-1Pの定量が不正確だった。本研究では, 超好熱性古細菌 Aeropyrum pernix の 1L-Ino-1P 合成酵素組換え体溶液を酵素として用いて, 1L-Ino-1P 調製の最適条件を検討し, 1L-Ino1Pの簡易定量法が正確な濃度を示している事をガスクロマトグラフィーで確認した。また, 1D-イノシトール1リン 酸(1D-Ino-1P) はPIP 合成酵素の基質にならないことを確認した。

キーワード : イノシトール,リン脂質, ホスファチジルイノシトールリン酸.

J UOEH(産業医大誌) 40(3)：217 - 224 (2018) 